\title{
Studi Mengenai Perlakuan Agregat Berukuran 2,38 mm - 4,75 mm sebagai Agregat Kasar dalam Campuran Beton
}

\author{
AHMAD RAMDANI, PRIYANTO SAELAN \\ Jurusan Teknik Sipil, Institut Teknologi Nasional, Bandung \\ Email: ahmadramdani434@gmail.com
}

\begin{abstract}
ABSTRAK
Batu pecah berukuran 2,38 mm - 4,75 mm tidak digunakan dalam campuran beton. Jika campuran beton dirancang menggunakan batu pecah ini sebagai agregat kasar, maka campuran beton yang dihasilkan diduga tidak akan mengalami segregasi untuk semua kelecakan, lebih homogen, dan jika diberi bahan tambahan superplasticizer diduga dapat dengan mudah berperilaku sebagai campuran beton memadat mandiri. Penelitian ini dilakukan untuk membuktikan dugaan tersebut. Penelitian dilakukan dengan kuat tekan rencana $30 \mathrm{MPa}$, slump $40 \mathrm{~mm}$ dan $100 \mathrm{~mm}$, tanpa dan dengan bahan tambahan superplasticizer dengan dosis $1 \%$ dan $1,5 \%$. Perancangan campuran beton dengan cara Dreux menggunakan faktor granular 0,40; 0,45; 0,50; dan 0,55. Pengujian kuat tekan pada benda uji silinder diameter $10 \mathrm{~cm}$ dan tinggi $20 \mathrm{~cm}$ membuktikan bahwa dugaan tersebut adalah benar, dan perancangan campuran beton dengan memperlakukan batu pecah berukuran 2,38 mm - 4,75 mm sebagai agregat kasar dapat dilakukan untuk faktor granular 0,40-0,50.
\end{abstract}

Kata kunci: batu pecah berukuran 2,38 $\mathrm{mm}-4,75 \mathrm{~mm}$,agregat kasar,superplasticizer

\begin{abstract}
$2.38 \mathrm{~mm}-4.75 \mathrm{~mm}$ crushed aggregate size is not used in concrete mix. If this crushed aggregate is used as coarse aggregate, the resulting concrete mix is assumed will not segregate in all workability, more homogeneous, and it will behave easily as self-compacting concrete by adding superplasticizer. This research was conducted to prove these assumption. Concrete mix with compressive strength of $30 \mathrm{MPa}, 40 \mathrm{~mm}$ and $100 \mathrm{~mm}$ slump is made using Dreux method with granular factor 0.40; 0.45; 0.50; and 0.55. The doses of superplasticizer is $1 \%$ and $1.5 \%$ by cement weight. Compressive strength tests of $10 \mathrm{~cm}$ diameter and $20 \mathrm{~cm}$ height cylinder diameter showed these assumption is true, and concrete mix can be designed using granular factor $0.40-0.50$.
\end{abstract}

Keywords: 2,38 mm - 4,75 mm crushed aggregate size, coarse aggregate, superplasticizer 


\section{PENDAHULUAN}

Secara umum agregat dibedakan berdasarkan ukurannya, yaitu agregat halus dan agregat kasar. SNI 03-2834-2000 mendefinisikan bahwa agregat halus adalah butiran yang mempunyai ukuran 0,15 mm - 4,75 mm, sedangkan agregat kasar adalah butiran yang mempunyai ukuran antara 4,75 mm - $40 \mathrm{~mm}$. Jika beton dibuat dengan ukuran maksimum butiran agregat kasar berdekatan dengan ukuran maksimum butiran agregat halus maka untuk semua tingkat kelecakan campuran beton segar, peluang terjadinya segregasi dapat dicegah. Penelitian dari Davey (1954) dalam Neville, A. M. (1981) yang menggunakan agregat kasar berukuran maksimum $20 \mathrm{~mm}$, telah membuktikan bahwa jika campuran beton dibuat dengan faktor air-semen yang sama, serta permukaan spesifik total yang sama, akan menghasilkan kuat tekan yang sama. Yang menarik dari penelitian Davey (1954) adalah salah satu campurannya menggunakan pasir bergradasi seragam dengan ukuran $150 \mu m-300 \mu m$, yang merupakan ukuran terkecil dari butiran pasir, serta menggunakan agregat kasar dengan gradasi seragam berukuran $10 \mathrm{~mm}-20 \mathrm{~mm}$. Berdasarkan campuran dari penelitian Davey ini, jika ukuran agregat kasar diperkecil ukuran minimumnya menjadi butiran berukuran 2,38 mm $-4,75 \mathrm{~mm}$, maka patut diduga agregat berukuran ini masih berperilaku sebagai agregat kasar. Dengan demikian ukuran agregat kasar dapat didefinisi ulang sebagai agregat yang berukuran lebih besar dari 2,38 mm, tidak lagi agregat yang berukuran lebih besar dari 4,75 mm. Agregat berukuran 2,38 mm - 4,75 mm diperlakukan sebagai agregat kasar. Jika campuran beton dirancang menggunakan agregat kasar berukuran 2,38 mm -4,75 mm, maka campuran beton yang dihasilkan diduga tidak akan mengalami segregasi untuk semua kelecakan, lebih homogen, dan jika diberi bahan tambahan superplasticizer diduga dapat dengan mudah berperilaku sebagai campuran beton memadat mandiri (self-compacting concrete).

\section{TINJAUAN PUSTAKA}

\subsection{Pengaruh Gradasi Agregat Terhadap Kuat Tekan Beton}

Penelitian mengenai pengaruh gradasi agregat dalam campuran beton terhadap kuat tekan beton telah dilakukan oleh Davey (1954) dalam Neville, A. M. (1981) yang hasilnya tertera pada Tabel 1. Dalam penelitian tersebut gradasi agregat dinyatakan sebagai permukaan spesifik total yaitu luas permukaan total agregat per satuan massa agregat.

Tabel 1. Pengaruh Gradasi Agregat Terhadap Kuat Tekan Beton

\begin{tabular}{|c|c|c|c|c|c|c|c|c|c|c|}
\hline \multicolumn{11}{|c|}{ Gradasi Agregat [\%] } \\
\hline $\begin{array}{l}\text { Ukuran } \\
\text { Butiran }\end{array}$ & $\begin{array}{c}300- \\
150 \\
\mu \mathrm{m}\end{array}$ & $\begin{array}{c}600- \\
300 \\
\mu \mathrm{m}\end{array}$ & $\begin{array}{c}1,20 \\
\mathrm{~mm}- \\
600 \mu \mathrm{m}\end{array}$ & $\begin{array}{c}2,40- \\
1,20 \\
\mathrm{~mm}\end{array}$ & $\begin{array}{c}4,76- \\
2,40 \\
\mathrm{~mm}\end{array}$ & $\begin{array}{c}9,52- \\
4,76 \\
\mathrm{~mm}\end{array}$ & $\begin{array}{c}19,05- \\
9,52 \\
\mathrm{~mm}\end{array}$ & \multirow{2}{*}{$\begin{array}{c}\text { Specific } \\
\text { Surface } \\
{\left[\mathrm{m}^{2} / \mathrm{kg}\right]}\end{array}$} & \multirow{2}{*}{$\begin{array}{c}\text { Rasio } \\
\text { Air / } \\
\text { Semen }\end{array}$} & \multirow{2}{*}{$\begin{array}{c}\text { Kuat } \\
\text { Tekan } \\
28 \\
\text { Hari } \\
\text { [MPa] }\end{array}$} \\
\hline ASTM & $\begin{array}{l}50- \\
100\end{array}$ & $\begin{array}{c}30- \\
50\end{array}$ & $16-30$ & 8-16 & $\begin{array}{c}3 / 16- \\
8\end{array}$ & $\begin{array}{l}3 / 8- \\
3 / 16\end{array}$ & $\begin{array}{c}3 / 4- \\
3 / 8\end{array}$ & & & \\
\hline $\mathrm{A}$ & 11,2 & 11,2 & 11,2 & 11,2 & 11,2 & 22,0 & 22,0 & 3,2 & 0,575 & 32,9 \\
\hline$B$ & 12,9 & 12,9 & 12,9 & 0 & 0 & 30,6 & 30,7 & 3,2 & 0,575 & 32,3 \\
\hline $\mathrm{C}$ & 15,4 & 15,4 & 0 & 0 & 0 & 34,6 & 34,6 & 3,2 & 0,575 & 32,8 \\
\hline $\mathrm{D}$ & 25,4 & 0 & 0 & 0 & 0 & 0 & 74,6 & 3,2 & 0,575 & 321 \\
\hline
\end{tabular}

(Sumber: Neville, A. M., 1981)

Berdasarkan hasil penelitian pada Tabel 1, Davey (1954) dalam Neville, A. M. (1981) membuktikan bahwa gradasi agregat yang berbeda pada masing-masing campuran beton tidak berpengaruh terhadap kuat tekan beton yang dihasilkan pada umur beton 28 hari selama nilai permukaan spesifik agregat dan faktor air-semen yang digunakan tetap. Hal ini juga berlaku untuk campuran beton yang memiliki gradasi ekstrim, menggunakan pasir bergradasi seragam berukuran $150 \mu m-300 \mu m$ dan agregat kasar bergradasi seragam berukuran 10 
$\mathrm{mm}-20 \mathrm{~mm}$ seperti yang terlihat pada campuran beton D. Penelitian terhadap pengaruh permukaan spesifik agregat terhadap kelecakan campuran beton segar pernah dilakukan juga oleh Newman dan Teychenne (1954) dalam Neville, A. M. (1981) yang hasilnya tertera pada Tabel 2. Kelecakan campuran beton segar dinyatakan dalam faktor kepadatan. Pada Tabel $\mathbf{2}$ dapat diketahui bahwa pada campuran beton dengan berbagai zona gradasi pasir yang berbeda, dengan nilai permukaan spesifik agregat yang sama, dan faktor air-semen yang sama akan menghasilkan kuat tekan beton yang tidak jauh berbeda dan kelecakan beton segar yang sangat berdekatan. Ditinjau dari permukaan spesifik yang tidak berubah, hasil penelitian Newman dan Teychenne (1954) ini memperlihatkan pola yang sama dengan penelitian Davey (1954) mengenai kedekatan hasil kuat tekan yang dihasilkan dari berbagai campuran yang digunakan. Dari kedua penelitian ini dapat disimpulkan bahwa berbagai gradasi agregat tidak akan berpengaruh terhadap kuat tekan beton dan kelecakan campuran beton segar selama permukaan spesifik total agregatnya sama.

Tabel 2. Pengaruh Permukaan Spesifik terhadap Kelecakan Campuran Beton Segar

\begin{tabular}{lcccc}
\hline \multicolumn{1}{c}{ Sifat-Sifat Beton } & \multicolumn{4}{c}{ Zona Gradasi Pasir } \\
\cline { 2 - 5 } & $\mathbf{1}$ & $\mathbf{2}$ & $\mathbf{3}$ & $\mathbf{4}$ \\
\hline Permukaan spesifik $\left[\mathrm{m}^{2} / \mathrm{kg}\right]$ & 2,55 & 2,55 & 2,55 & 2,55 \\
\hline Persen agregat lolos saringan $4,76 \mathrm{~mm}$ & 46 & 36 & 29 & 24 \\
\hline Proporsi volume campuran & $1: 2 \frac{1}{2}: 3 \frac{1}{2}$ & $1: 2: 4$ & $1: 1 \frac{1}{2}: 4 \frac{1}{2}$ & $1: 1 \frac{1}{4}: 4 \frac{1}{4}$ \\
\hline Air/semen [dalam berat] & 0,60 & 0,60 & 0,60 & 0,60 \\
\hline Faktor kepadatan & 0,92 & 0,93 & 0,93 & 0,94 \\
\hline Kuat tekan 28 hari [MPa] & 27,1 & 28,1 & 29,2 & 29,0 \\
\hline
\end{tabular}

(Sumber: Neville, A. M., 1981)

Jika pada Tabel $\mathbf{2}$ dikembangkan campuran E dengan cara memodifikasi ukuran butiran agregat kasar pada campuran D tetapi menggunakan agregat kasar berukuran 2,38 mm $4,75 \mathrm{~mm}$ maka permukaan spesifik total agregat menjadi lebih besar dari $3,2 \mathrm{~m}^{2} / \mathrm{kg}$. Agar permukaan spesifik agregat tetap 3,2 $\mathrm{m}^{2} / \mathrm{kg}$ maka secara teoritis butiran ukuran $150 \mu \mathrm{m}-300$ $\mu m$ harus dikurangi dan disebar pada ukuran lebih besar dari $150 \mu m-300 \mu m$ sedemikian rupa sehingga permukaan spesifik total agregatnya tetap 3,2 $\mathrm{m}^{2} / \mathrm{kg}$. Dengan demikian maka kuat tekan beton yang dihasilkan pada campuran $\mathrm{E}$ diharapkan akan berdekatan dengan campuran A, B, C, dan D sebelum dimodifikasi. Campuran $E$ ini merupakan campuran beton berbutir halus dimana butiran agregat berukuran $2,38 \mathrm{~mm}-4,75 \mathrm{~mm}$ diperlakukan sebagai agregat kasar. Jika campuran beton dirancang menggunakan agregat kasar berukuran 2,38 $\mathrm{mm}-4,75 \mathrm{~mm}$, maka campuran beton yang dihasilkan diduga tidak akan mengalami segregasi untuk semua kelecakan, lebih homogen, dan jika diberi bahan tambahan superplasticizer diduga dapat dengan mudah berperilaku sebagai campuran beton memadat mandiri (selfcompacting concrete). Hal ini disebabkan karena ukuran butiran agregat kasar tidak berbeda jauh dengan ukuran maksimum agregat halus.

\section{METODE PENELITIAN}

\subsection{Prosedur Penelitian}

Prosedur penelitian dilakukan dengan metoda yang tertera pada Gambar 1. 


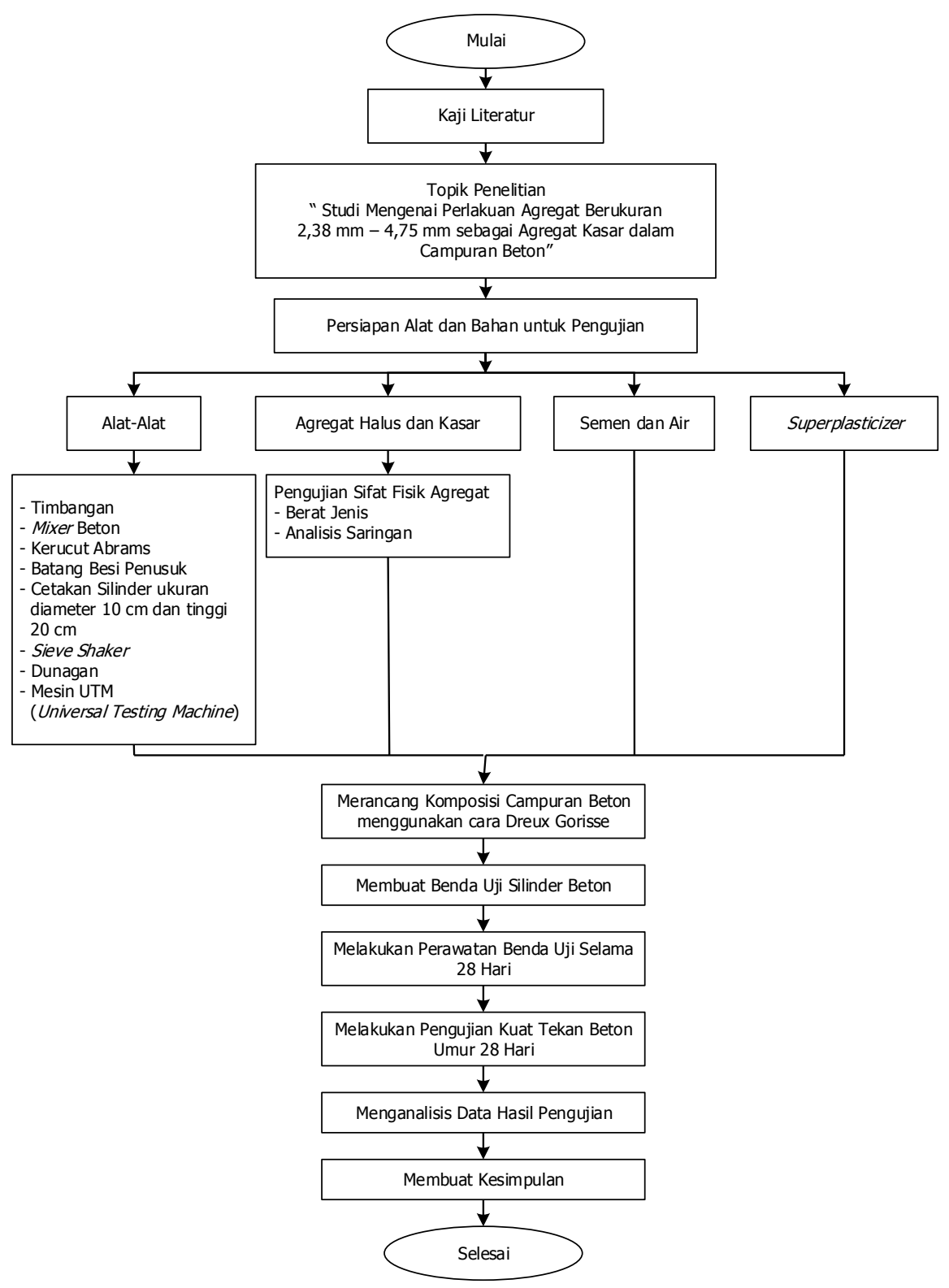

Gambar 1. Bagan Alir Metode Penelitian

\subsection{Data Penelitian}

Data penelitian yang digunakan terdiri dari data hasil pengujian sifat fisik agregat dan data komposisi campuran beton. Data hasil pengujian sifat fisik agregat meliputi berat jenis, dan modulus kehalusan seperti yang tertera pada Tabel $\mathbf{3}$.

Tabel 3. Hasil Pengujian Sifat Fisik Agregat

\begin{tabular}{lcccc}
\hline \multicolumn{1}{c}{ Parameter } & Semen & $\begin{array}{c}\text { Agregat } \\
\text { Kasar }\end{array}$ & $\begin{array}{c}\text { Agregat } \\
\text { Halus }\end{array}$ \\
\hline Berat jenis kondisi SSD & {$\left[\mathrm{kg} / \mathrm{m}^{3}\right]$} & 3.150 & 2.500 & 2.667 \\
\hline Berat jenis kondisi kering udara & {$\left[\mathrm{kg} / \mathrm{m}^{3}\right]$} & - & 2.373 & 2.595 \\
\hline Modulus Kehalusan & {$[\mathrm{FM}]$} & - & - & 2,316 \\
\hline
\end{tabular}

\subsection{Variabel Penelitian}

Variabel pada penelitian ini terdiri dari:

(1) nilai s/ump sebesar $40 \mathrm{~mm}$ dan $100 \mathrm{~mm}$;

(2) faktor granular $G(0,40 ; 0,45 ; 0,50$; dan 0,55$)$; 
(3) campuran beton dirancang 2 macam yaitu tanpa bahan superplasticizer dan dengan superplasticizer dengan dosis $1 \%-1,5 \%$ dari berat semen.

\subsection{Analisis Data}

Analisis data hasil pengujian dilakukan dengan cara membuat grafik yang menggambarkan hubungan antara kuat tekan rencana terhadap faktor granular $(G)$ berdasarkan tabel komposisi campuran.

\section{HASIL PENELITIAN DAN PEMBAHASAN}

\subsection{Hasil Penelitian}

Hasil-hasil penelitian ditunjukkan pada Tabel 4 sampai dengan Tabel 9, dan Gambar 2 sampai dengan Gambar 4.

Tabel 4. Hasil Pengujian untuk Komposisi $1 \mathrm{~m}^{3}$ Campuran Beton $\boldsymbol{f}_{c}^{\prime}=30 \mathrm{MPa}$, Slump Rencana $40 \mathrm{~mm}$, Tanpa SP

\begin{tabular}{|c|c|c|c|c|}
\hline \multirow{2}{*}{ Bahan } & \multicolumn{4}{|c|}{ Jumlah Bahan untuk Nilai $G$ Tertentu [kg] } \\
\hline & 0,40 & 0,45 & 0,50 & 0,55 \\
\hline Semen & 553,5 & 492 & 467,4 & 430,5 \\
\hline Pasir $0,15 \mathrm{~mm}-2,38 \mathrm{~mm}$ & 592,1 & 800,1 & 888,11 & 978,79 \\
\hline Batu Pecah 2,38 mm - 4,75 mm & 842,5 & 715 & 637,5 & 587,5 \\
\hline Semula & 244,89 & 237,9 & 244,59 & 241,45 \\
\hline Tambahan & 14,35 & 15,15 & 15,26 & 15,67 \\
\hline Superplasticizer [SP] & - & - & - & - \\
\hline Slump aktual [cm] & 2 & 0,5 & 1,5 & 0 \\
\hline Umur pengujian [hari] & 14 & 14 & 14 & 14 \\
\hline $\boldsymbol{f}_{\boldsymbol{c}}^{\prime}$ rata-rata pengujian $[\mathrm{MPa}]$ & 26,43 & 22,72 & 25,48 & 19,11 \\
\hline $\begin{array}{c}f_{c}^{\prime} \text { rata-rata } 28 \text { hari dari umur } \\
\text { pengujian }[\mathrm{MPa}]\end{array}$ & 30,04 & 25,82 & 28,95 & 21,71 \\
\hline Fenomena segregasi & $\begin{array}{l}\text { Tidak } \\
\text { terjadi }\end{array}$ & $\begin{array}{l}\text { Tidak } \\
\text { terjadi }\end{array}$ & $\begin{array}{l}\text { Tidak } \\
\text { terjadi }\end{array}$ & $\begin{array}{l}\text { Tidak } \\
\text { terjadi }\end{array}$ \\
\hline
\end{tabular}


Tabel 5. Hasil Pengujian untuk Komposisi $1 \mathrm{~m}^{3}$ Campuran Beton $f_{c}^{\prime}=30 \mathrm{MPa}$, Slump rencana $40 \mathrm{~mm}$, dengan $\mathrm{SP}=1 \%$ Berat Semen

\begin{tabular}{|c|c|c|c|c|c|}
\hline \multirow{2}{*}{\multicolumn{2}{|c|}{ Bahan }} & \multicolumn{4}{|c|}{ Jumlah Bahan untuk Nilai $G$ Tertentu [kg] } \\
\hline & & 0,40 & 0,45 & 0,50 & 0,55 \\
\hline \multicolumn{2}{|c|}{ Semen } & 553,5 & 492 & 467,4 & 430,5 \\
\hline \multicolumn{2}{|c|}{ Pasir $0,15 \mathrm{~mm}-2,38 \mathrm{~mm}$} & 592,1 & 800,1 & 888,11 & 978,79 \\
\hline \multicolumn{2}{|c|}{ Batu Pecah 2,38 mm - 4,75 mm } & 842,5 & 715 & 637,5 & 587,5 \\
\hline \multirow{2}{*}{ Air } & Semula & 244,89 & 237,9 & 244,59 & 241,45 \\
\hline & Tambahan & 14,35 & 15,15 & 15,26 & 15,67 \\
\hline \multicolumn{2}{|c|}{ Superplasticizer [SP] } & 2,77 & 2,46 & 2,34 & 2,15 \\
\hline \multicolumn{2}{|c|}{ Slumpslow aktual [cm] } & 61 & 50 & 58 & 49 \\
\hline \multicolumn{2}{|c|}{ Umur pengujian [hari] } & 14 & 14 & 19 & 18 \\
\hline \multicolumn{2}{|c|}{$\boldsymbol{f}_{c}^{\prime}$ rata-rata pengujian $[\mathrm{MPa}]$} & 26,11 & 21,66 & 17,52 & 15,29 \\
\hline \multicolumn{2}{|c|}{$\begin{array}{c}f_{c}^{\prime} \text { rata-rata } 28 \text { hari dari umur } \\
\text { pengujian [MPa] }\end{array}$} & 29,68 & 24,61 & 18,83 & 16,62 \\
\hline \multicolumn{2}{|c|}{ Fenomena segregasi } & $\begin{array}{l}\text { Tidak } \\
\text { terjadi }\end{array}$ & $\begin{array}{l}\text { Tidak } \\
\text { terjadi }\end{array}$ & $\begin{array}{l}\text { Tidak } \\
\text { terjadi }\end{array}$ & $\begin{array}{l}\text { Tidak } \\
\text { terjadi }\end{array}$ \\
\hline
\end{tabular}

Tabel 6. Hasil Pengujian untuk Komposisi $1 \mathrm{~m}^{3}$ Campuran Beton $f_{c}{ }^{\prime}=30 \mathrm{MPa}$, Slump rencana $40 \mathrm{~mm}$, dengan SP $=1,5 \%$ Berat Semen

\begin{tabular}{|c|c|c|c|c|c|}
\hline \multirow{2}{*}{\multicolumn{2}{|c|}{ Bahan }} & \multicolumn{4}{|c|}{ Jumlah Bahan untuk Nilai $G$ Tertentu [kg] } \\
\hline & & 0,40 & 0,45 & 0,50 & 0,55 \\
\hline \multicolumn{2}{|c|}{ Semen } & 553,5 & 492 & 467,4 & 430,5 \\
\hline \multicolumn{2}{|c|}{ Pasir $0,15 \mathrm{~mm}-2,38 \mathrm{~mm}$} & 592,1 & 800,1 & 888,11 & 978,79 \\
\hline \multicolumn{2}{|c|}{ Batu Pecah 2,38 mm - 4,75 mm } & 842,5 & 715 & 637,5 & 587,5 \\
\hline \multirow{2}{*}{ Air } & Semula & 244,89 & 237,9 & 244,59 & 241,45 \\
\hline & Tambahan & 14,35 & 15,15 & 15,26 & 15,67 \\
\hline \multicolumn{2}{|c|}{ Superplasticizer [SP] } & 5.54 & 4,92 & 4,67 & 4,3 \\
\hline \multicolumn{2}{|c|}{ Slumpflow aktual [cm] } & 66 & 52 & 55 & 50 \\
\hline \multicolumn{2}{|c|}{ Umur pengujian [hari] } & 14 & 14 & 19 & 18 \\
\hline \multicolumn{2}{|c|}{$f_{c}^{\prime}$ rata-rata pengujian $[\mathrm{MPa}]$} & 23,25 & 21,66 & 17,52 & 12,74 \\
\hline \multicolumn{2}{|c|}{$\begin{array}{c}f_{c}^{\prime} \text { rata-rata } 28 \text { hari dari umur } \\
\text { pengujian [MPa] }\end{array}$} & 26,42 & 24,61 & 18,83 & 13,85 \\
\hline \multicolumn{2}{|c|}{ Fenomena segregasi } & $\begin{array}{l}\text { Tidak } \\
\text { terjadi }\end{array}$ & $\begin{array}{l}\text { Tidak } \\
\text { terjadi }\end{array}$ & $\begin{array}{l}\text { Tidak } \\
\text { terjadi }\end{array}$ & $\begin{array}{l}\text { Tidak } \\
\text { terjadi }\end{array}$ \\
\hline
\end{tabular}


Tabel 7. Hasil Pengujian untuk Komposisi $1 \mathrm{~m}^{3}$ Campuran Beton $f_{c}{ }^{\prime}=30 \mathrm{MPa}$, Slump rencana $100 \mathrm{~mm}$, Tanpa SP

\begin{tabular}{|c|c|c|c|c|c|}
\hline \multirow{2}{*}{\multicolumn{2}{|c|}{ Bahan }} & \multicolumn{4}{|c|}{ Jumlah Bahan untuk Nilai $G$ Tertentu [kg] } \\
\hline & & 0,40 & 0,45 & 0,50 & 0,55 \\
\hline \multicolumn{2}{|c|}{ Semen } & 602,7 & 541,2 & 504,3 & 467,4 \\
\hline \multicolumn{2}{|c|}{ Pasir $0,15 \mathrm{~mm}-2,38 \mathrm{~mm}$} & 711,29 & 800,1 & 888,11 & 978,79 \\
\hline \multicolumn{2}{|c|}{ Batu Pecah 2,38 mm - 4,75 mm } & 638,25 & 615 & 557,5 & 507,5 \\
\hline \multirow{2}{*}{ Air } & Semula & 266,67 & 261,71 & 263,88 & 262,14 \\
\hline & Tambahan & 26,99 & 28,30 & 28,91 & 29,73 \\
\hline \multicolumn{2}{|c|}{ Superplasticizer [SP] } & - & - & - & - \\
\hline \multicolumn{2}{|c|}{ Slump aktual $[\mathrm{cm}]$} & 3 & 5,5 & 4,7 & 4 \\
\hline \multicolumn{2}{|c|}{ Umur pengujian [hari] } & 14 & 14 & 14 & 14 \\
\hline \multicolumn{2}{|c|}{$\boldsymbol{f}_{c}^{\prime}$ rata-rata pengujian $[\mathrm{MPa}]$} & 23,78 & 24,84 & 22,61 & 17,20 \\
\hline \multicolumn{2}{|c|}{$\begin{array}{c}f_{c}^{\prime} \text { rata-rata } 28 \text { hari dari umur } \\
\text { pengujian [MPa] }\end{array}$} & 27,02 & 28,23 & 25,69 & 19,54 \\
\hline \multicolumn{2}{|c|}{ Fenomena segregasi } & $\begin{array}{l}\text { Tidak } \\
\text { terjadi }\end{array}$ & $\begin{array}{l}\text { Tidak } \\
\text { terjadi }\end{array}$ & $\begin{array}{l}\text { Tidak } \\
\text { terjadi }\end{array}$ & $\begin{array}{c}\text { Tidak } \\
\text { terjadi }\end{array}$ \\
\hline
\end{tabular}

Tabel 8. Hasil Pengujian untuk Komposisi $1 \mathrm{~m}^{3}$ Campuran Beton $f_{c}{ }^{\prime}=30 \mathrm{MPa}$, Slump rencana $100 \mathrm{~mm}$, dengan SP $=1 \%$ Berat Semen

\begin{tabular}{|c|c|c|c|c|c|}
\hline \multirow{2}{*}{\multicolumn{2}{|c|}{ Bahan }} & \multicolumn{4}{|c|}{ Jumlah Bahan untuk Nilai $G$ Tertentu [kg] } \\
\hline & & 0,40 & 0,45 & 0,50 & 0,55 \\
\hline \multicolumn{2}{|c|}{ Semen } & 602,7 & 541,2 & 504,3 & 467,4 \\
\hline \multicolumn{2}{|c|}{ Pasir $0,15 \mathrm{~mm}-2,38 \mathrm{~mm}$} & 711,29 & 800,1 & 888,11 & 978,79 \\
\hline \multicolumn{2}{|c|}{ Batu Pecah 2,38 mm - 4,75 mm } & 638,25 & 615 & 557,5 & 507,5 \\
\hline \multirow{2}{*}{ Air } & Semula & 266,67 & 261,71 & 263,88 & 262,14 \\
\hline & Tambahan & 26,99 & 28,30 & 28,91 & 29,73 \\
\hline \multicolumn{2}{|c|}{ Superplasticizer [SP] } & 3,01 & 2,71 & 2,52 & 2,34 \\
\hline \multicolumn{2}{|c|}{ Slumpflow aktual [cm] } & 78,5 & 66,5 & 51 & 50 \\
\hline \multicolumn{2}{|c|}{ Umur pengujian [hari] } & 16 & 15 & 12 & 11 \\
\hline \multicolumn{2}{|c|}{$\boldsymbol{f}_{c}^{\prime}$ rata-rata pengujian $[\mathrm{MPa}]$} & 27,71 & 27,81 & 22,61 & 22,08 \\
\hline \multicolumn{2}{|c|}{$\begin{array}{c}f_{c}^{\prime} \text { rata-rata } 28 \text { hari dari umur } \\
\text { pengujian }[\mathrm{MPa}]\end{array}$} & 30,79 & 31,25 & 27,77 & 28,26 \\
\hline \multicolumn{2}{|c|}{ Fenomena segregasi } & $\begin{array}{l}\text { Tidak } \\
\text { terjadi }\end{array}$ & $\begin{array}{l}\text { Tidak } \\
\text { terjadi }\end{array}$ & $\begin{array}{l}\text { Tidak } \\
\text { terjadi }\end{array}$ & $\begin{array}{c}\text { Tidak } \\
\text { terjadi }\end{array}$ \\
\hline
\end{tabular}


Tabel 9. Hasil Pengujian untuk Komposisi $1 \mathrm{~m}^{3}$ Campuran Beton $f_{c}{ }^{\prime}=30 \mathrm{MPa}$, Slump rencana $100 \mathrm{~mm}$, dengan $\mathrm{SP}=1,5 \%$ Berat Semen

\begin{tabular}{|c|c|c|c|c|c|}
\hline \multirow{2}{*}{\multicolumn{2}{|c|}{ Bahan }} & \multicolumn{4}{|c|}{ Jumlah Bahan untuk Nilai $G$ Tertentu [kg] } \\
\hline & & 0,40 & 0,45 & 0,50 & 0,55 \\
\hline \multicolumn{2}{|c|}{ Semen } & 602,7 & 541,2 & 504,3 & 467,4 \\
\hline \multicolumn{2}{|c|}{ Pasir $0,15 \mathrm{~mm}-2,38 \mathrm{~mm}$} & 711,29 & 800,1 & 888,11 & 978,79 \\
\hline \multicolumn{2}{|c|}{ Batu Pecah 2,38 mm - 4,75 mm } & 638,25 & 615 & 557,5 & 507,5 \\
\hline \multirow{2}{*}{ Air } & Semula & 266,67 & 261,71 & 263,88 & 262,14 \\
\hline & Tambahan & 26,99 & 28,30 & 28,91 & 29,73 \\
\hline \multicolumn{2}{|c|}{ Superplasticizer [SP] } & 6,03 & 5,41 & 5,04 & 4,67 \\
\hline \multicolumn{2}{|c|}{ Slumpflow aktual [cm] } & 74 & 75 & 55 & 52 \\
\hline \multicolumn{2}{|c|}{ Umur pengujian [hari] } & 16 & 15 & 12 & 11 \\
\hline \multicolumn{2}{|c|}{$\boldsymbol{f}_{c}^{\prime}$ rata-rata pengujian $[\mathrm{MPa}]$} & 21,23 & 22,08 & 20,38 & 20,06 \\
\hline \multicolumn{2}{|c|}{$\begin{array}{c}f_{c}^{\prime} \text { rata-rata } 28 \text { hari dari umur } \\
\text { pengujian [MPa] }\end{array}$} & 23,59 & 27,12 & 25,03 & 25,68 \\
\hline \multicolumn{2}{|c|}{ Fenomena segregasi } & $\begin{array}{l}\text { Tidak } \\
\text { terjadi }\end{array}$ & $\begin{array}{l}\text { Tidak } \\
\text { terjadi }\end{array}$ & $\begin{array}{l}\text { Tidak } \\
\text { terjadi }\end{array}$ & $\begin{array}{c}\text { Tidak } \\
\text { terjadi }\end{array}$ \\
\hline
\end{tabular}

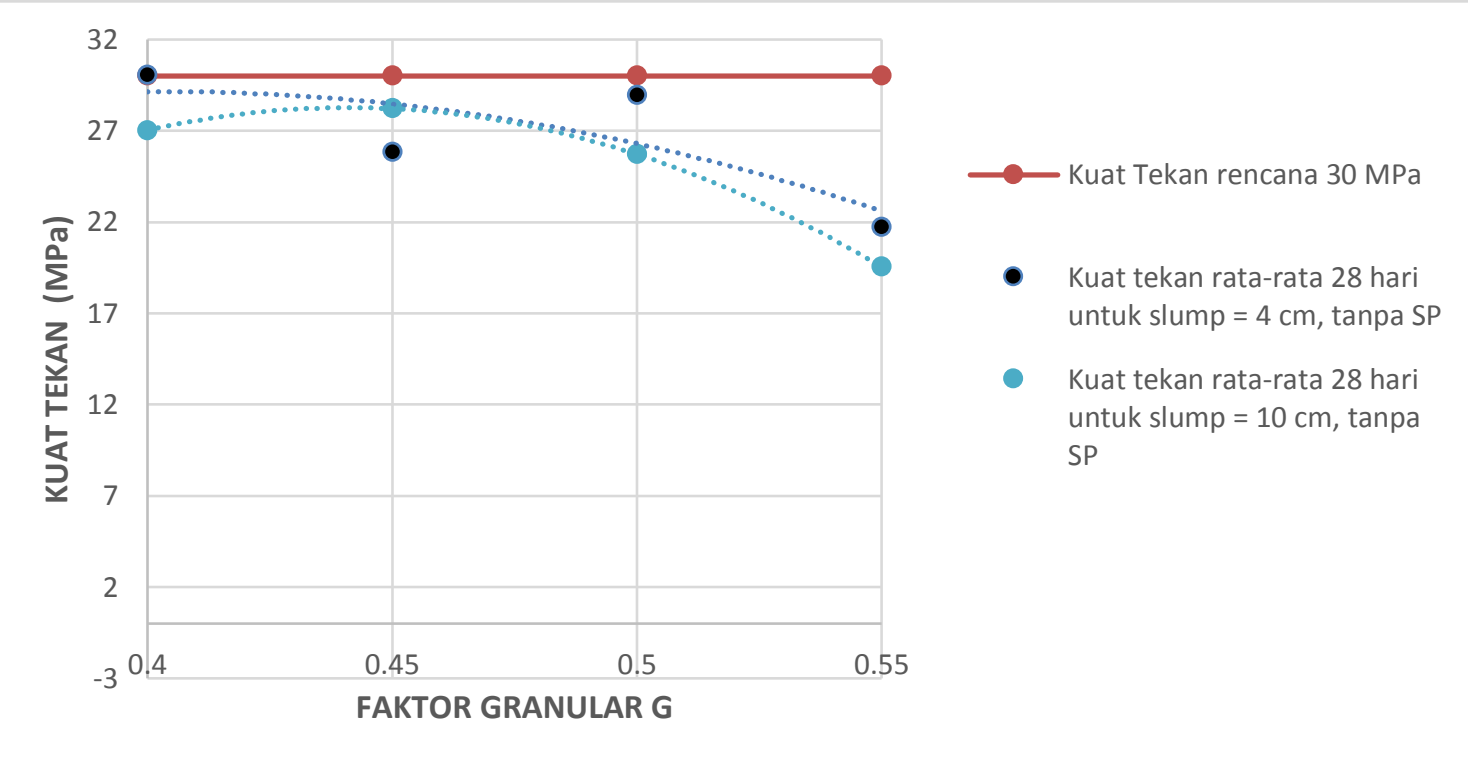

Gambar 2. Hubungan antara kuat tekan rata-rata terhadap faktor granular untuk s/ump rencana $4 \mathrm{~cm}$ dan s/ump rencana $10 \mathrm{~cm}$ tanpa SP 


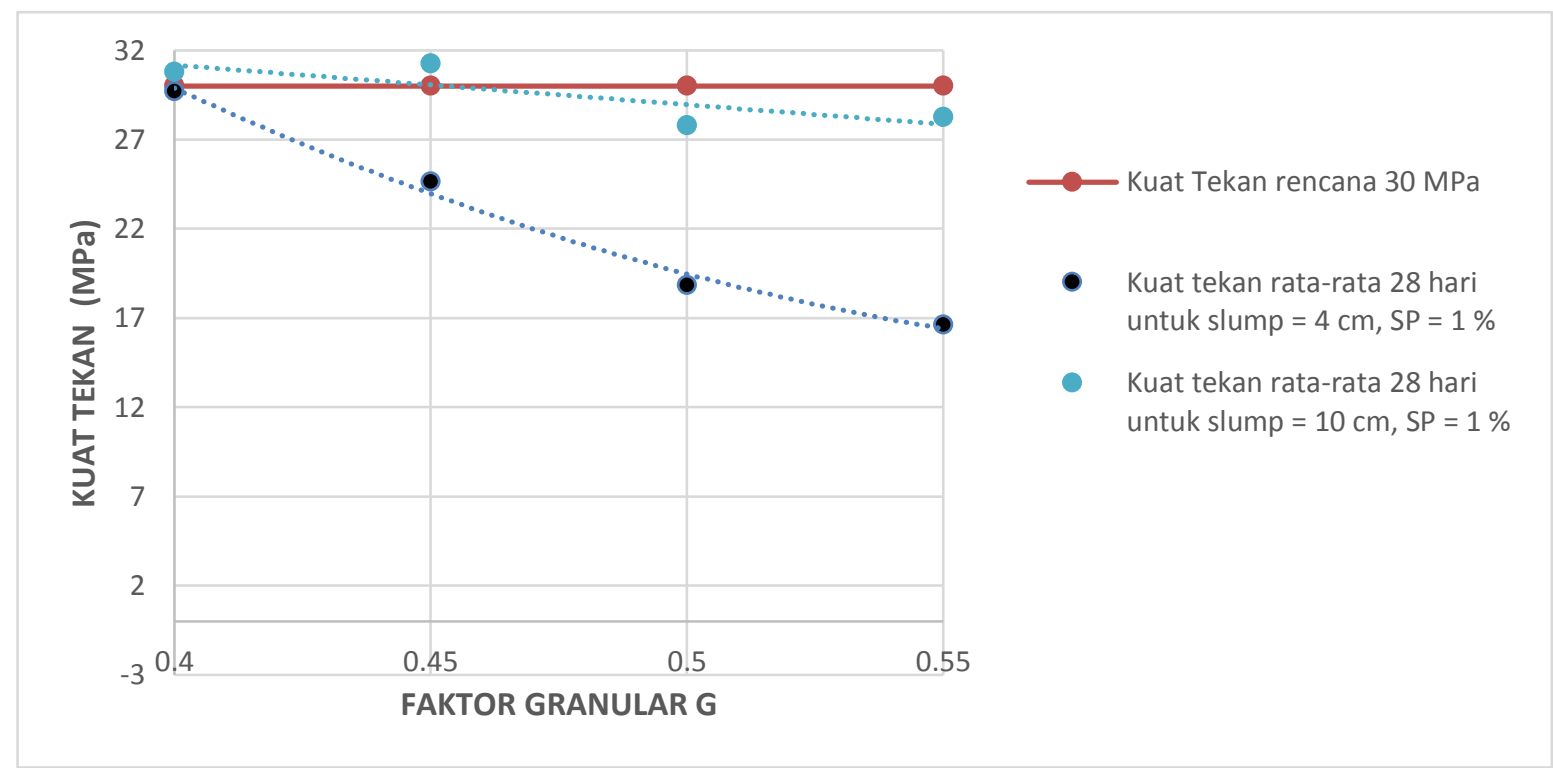

Gambar 3. Hubungan antara kuat tekan rata-rata terhadap faktor granular untuk s/ump rencana $4 \mathrm{~cm}$ dan s/ump rencana $10 \mathrm{~cm}$ dengan $S P=1 \%$ berat semen

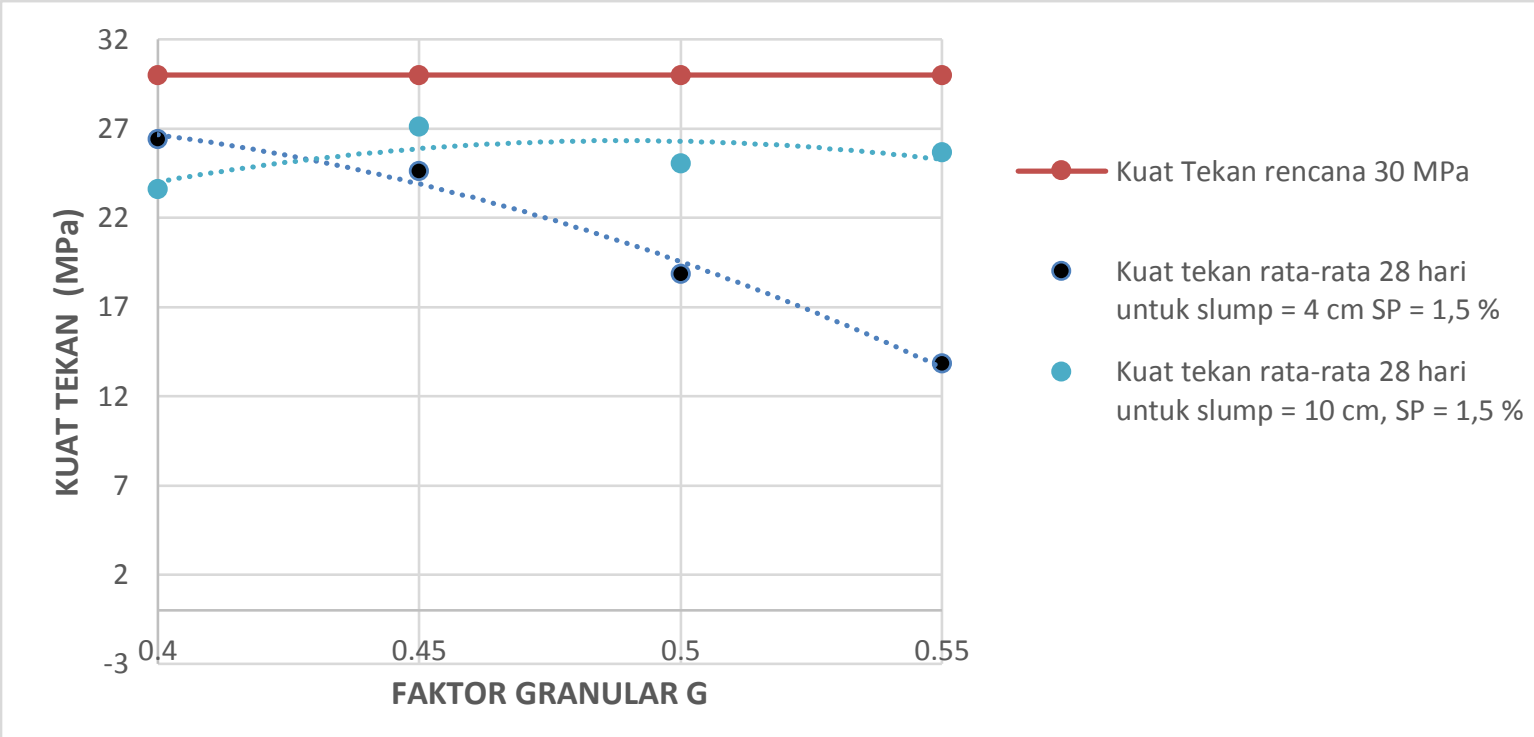

Gambar 4. Hubungan antara kuat tekan rata-rata terhadap faktor granular untuk slump rencana $4 \mathrm{~cm}$ dan s/ump rencana $10 \mathrm{~cm}$ dengan $S P=1,5 \%$ berat semen

\subsection{Pembahasan Hasil Penelitian}

Berdasarkan data hasil pengujian pada tabel komposisi campuran dan grafik hubungan antara kuat tekan rata-rata 28 hari terhadap faktor granular diketahui bahwa:

(1) dari hasil pengujian yang diperlihatkan pada Gambar 2. yaitu untuk campuran beton tanpa $\mathrm{SP}$, kuat tekan uji yang cenderung mendekati kuat tekan rencana terjadi pada faktor granular 0,40-0,50 dan dengan nilai s/ump $40 \mathrm{~mm}$. Oleh karena itu dengan faktor granular 0,40-0,50 masih dapat diupayakan ketercapaian kuat tekan yang direncanakan. Terjadi penurunan kuat tekan uji sehingga tidak mencapai kuat tekan prediksi. Penelusuran penyebab fenomena ini dilakukan dengan memperhatikan komposisi campuran. Berdasarkan penelusuran ini tidak didapatkan penyebab yang jelas terjadinya penurunan 
kuat tekan. Oleh karena itu penyebab terjadinya hal ini diduga berasal dari kondisi benda uji yang kurang baik akurasi bentuknya.

(2) hasil pengujian yang disajikan pada Gambar 3. juga memperlihatkan kecenderungan hasil yang sama dengan hasil pada campuran yang tanpa SP, yaitu pada faktor granular 0,40 kuat tekan pengujian sangat berdekatan dengan kuat tekan rencana. Hal ini juga terjadi jika berat pasir tidak melebihi berat agregat kasar;

(3) sesuai dengan dugaan bahwa campuran beton tidak akan mengalami segregasi jika ukuran maksimum agregat kasar mendekati ukuran maksimum pasir, maka dugaan ini terbukti adanya dan homogenitas beton secara visual terlihat sangat baik;

(4) penambahan SP dalam campuran beton menyebabkan campuran beton bersifat memadat mandiri dengan nilai s/umpflow $490 \mathrm{~mm}-785 \mathrm{~mm}$;

(5) pemadatan campuran beton dengan menggunakan ukuran maksimum agregat kasar yang berdekatan dengan ukuran maksimum agregat halus lebih mudah jika dibandingkan dengan ukuran maksimum agregat kasar yang berjauhan dengan ukuran maksium agregat halus.

\section{KESIMPULAN}

Berdasarkan data dari hasil penelitian yang telah dilakukan disimpulkan bahwa:

(1) agregat berukuran 2,38 mm - 4,75 mm dapat diperlakukan sebagai agregat kasar dalam campuran beton;

(2) cara perancangan campuran beton untuk ukuran agregat berukuran 4,75 mm - $40 \mathrm{~mm}$ dapat digunakan untuk agregat berukuran seragam 2,38 mm - 4,75 mm;

(3) jika perancangan campuran beton menggunakan cara Dreux, maka faktor granular yang digunakan yaitu $0,40-0,50$;

(4) campuran beton dengan menggunakan 2,38 $\mathrm{mm}-4,75 \mathrm{~mm}$ dapat dengan mudah memadat mandiri jika diberi SP dengan dosis $1 \%$ dan $1,5 \%$.

\section{DAFTAR RUJUKAN}

Badan Standardisasi Nasional. (2000). SNI 03-2834-2000 Tata Cara Pembuatan Rencana Campuran Beton Normal. Jakarta: Badan Standardisasi Nasional.

Neville, A. M. (1981). Properties of Concrete ( $3^{\text {rd }}$ ed.). England: Pearson Education Limited. 